\title{
PRIORITIZATION OF PETROLEUM SUPPLY CHAINS' DISRUPTION MANAGEMENT STRATEGIES USING COMBINED FRAMEWORK OF BSC APPROACH, FUZZY AHP AND FUZZY CHOQUET INTEGRAL OPERATOR
}

\author{
Fatemeh GHASEMZADEH ${ }^{1}$, Mahsa PISHDAR ${ }^{2}$, \\ Jurgita ANTUCHEVIČIENE $\dot{E}^{3}$
}

\author{
${ }^{1,2}$ Industrial Management Department, Faculty of Management and Accounting, \\ Allameh Tabataba'i University, Dehkadeh-ye-Olympic (Campus), Tehran, Iran \\ ${ }^{3}$ Department of Construction Management and Real Estate, Faculty of Civil Engineering, \\ Vilnius Gediminas Technical University, Sauletekio al. 11, 10223 Vilnius, Lithuania \\ E-mails: ${ }^{1}$ ghasemzadeh.fa@gmail.com; ${ }^{2}$ mahsa.pishdar@yahoo.com; \\ 3jurgita.antucheviciene@vgtu.lt (corresponding author)
}

Received 27 Feb 2017; accepted 12 Sep 2017

\begin{abstract}
Industries in every sector have observed tangible losses from a broad range of disruptions during recent years. Factors such as globalization and outsourcing have made supply chains more sophisticated and this makes disruption management more necessary. Any disruption in each part of supply chain makes the whole supply chain face derangement and at last, ultimate customers realize the shaped disadvantages. Since avoidance of disruption occurrence is not always possible, application of different strategies with the aid of minimization of negative effects seems necessary. That is why in this paper, different strategies for disruption management in petroleum products supply chain and suitable criteria for prioritizing them are recognized via Balanced Score Card approach measures. After that, by application of fuzzy Analytical Hierarchy Process and intuitionistic fuzzy Choquet integral operator, their priorities are specified in order to make a guideline for managers to set proper plans and manage such disruptions more accurately.
\end{abstract}

Keywords: supply chain, petroleum products, disruption management strategies, BSC approach, intuitionistic fuzzy, Choquet integral operator.

JEL Classification: C61, D81, F10, Q31.

\section{Introduction}

A supply chain is a network that is constituted from suppliers till distribution centres and final customers. So, it should be considered that each manufacturing system or service provider is a part of a special supply chain (Paul et al. 2017).

Diversity of members in supply chains and other governmental and social pressures such as environmental laws make the supply chain management sophisticated and increase the vulnerability of supply chain toward various disruptions' occurrence. Since 
in a global supply chain, a firm's performance is more dependent on the various variables such as the performance of its extended supply chain network (Giri, Sarker 2017; Kamalahmadi, Parast 2016).

Before globalization expansion in supply chains, considered risk factors were local ones like natural disasters, social instability, etc. but nowadays such events within a country also can affect other supply chains somewhere else in the world (Behdani 2013). Current developments, such as "just-in-time" and lean operations, aid firms in reducing waste and smoothing its operations but contribute to a more risk-sensitive environment. This is because any hiccup that transpires within the supply chain will cause delay and even disruption (Paul et al. 2017).

Many definitions of disruption exist in the supply chain literature. Snyder et al. (2012), believe that disruptions are random and discrete events that cause an echelon of the supply chain to stop working for a random period of time. Moreover, Chopra and Sodhi (2004) state that disruption is a type or source of risk in the supply chain, which is unpredictable and rare but often quite damaging. Uncertainty and risk are related keywords of disruption that are often used in the literature. The most suitable definition of supply chain disruption is related to the definition of supply chain risk, as stated by Tang and Musa (2011), which they refer to as (i) events with small probability but that may occur abruptly and (ii) these events bring substantial negative consequences to the system.

The results of an international extended investigation which is conducted by the Business Continuity Institute (BCI) in 2016 show that $70 \%$ of companies worldwide are prone to at least one disruption every year (Alcantara, Riglietti 2016). Disruptions convey changes in operational plans which need more attention and necessitate re-planning (Pender et al. 2013). The addressed disruptions in studies vary in a vast range from a plant fire to global catastrophes like tsunami in 2004 (Stecke, Kumar 2009).

These disruptions are raised by factors such as climatic conditions or global climate change, soil management, plagues and diseases and producers' strategies. A supply shock can make the petroleum refining industry compelled to increase its gasoline output or increase level of liquid fuel imports. Even a combination of both alternatives may shape the solution (de Barros, Szklo 2015).

Type of industry and its importance to meet the needs of the community can intensify or reduce the effects of such disruptions. It is obvious that petroleum industry role in satisfying citizens' needs of energy is undeniable and its supply chain is one of the most complicated ones. Actually, petroleum industry is characterized as a complicated supply chain and highly capital intensive which can be faced with different disruptions (Kazemi, Szmerekovsky 2015).

From managerial point of view, it's believed that mitigation strategies are expensive and inefficient but Stecke and Kumar (Stecke, Kumar 2009) claim that from the quality research of the 1970s, well-developed strategies can increase efficiency. So it is reasonable that when organizations find that their supply chains are vulnerable to disruptions, put more attention on planning in order to reduce the likelihood and severity of the impact of such disorders. This matter can be done by the choice of suitable disruption 
management strategies. Since there are different strategies in this domain and each of them has its own risks, it is better to set a proper approach for the selection of a suitable strategy which is main goal of this paper.

Disruptions like natural disasters threat the continuity and resilience of petroleum supply chain too and since energy has an undeniable role in every aspect of today world function, it can be said that such disruptions may have catastrophic macro-economic consequences. For instance, the American Petroleum Institute estimated total damage by Katrina and Rita to energy infrastructure in the Gulf Coast to be between $\$ 18$ billion and $\$ 32$ billion (Officials 2006). It should be also noted that unplanned global oil supply disruptions averaged more than 3.6 million barrels per day (b/d) in May 2016 which is the highest monthly level recorded from when EIA ${ }^{1}$ started tracking global disruptions in January 2011 (EIA 2016). This shows the necessity of disruption management in this industry as a whole. However, despite the need, the number of studies which have considered the whole petroleum supply chain and its related disruptions are not high.

That is why in this paper a combination framework from Balanced Score Card (BSC), fuzzy Analytical Hierarchy Process (AHP) and intuitionistic fuzzy Choquet integral operator is applied to prioritize strategies and make a practical algorithm for decision makers to find appropriate strategy in their organizations. As BSC is a proven tool in Strategy Execution in both the public and private sector which represents a balanced approach for SCM (Sharma, Bhagwat 2007) we choose it as a tool for decision criteria extraction. Then Fuzzy AHP is used as decision making methodology in vague situations which is well fitted with BSC but was ignored in previous studies. Another novelty of this study is prioritization of strategies from different perspectives in supply chain which gives different results and helps managers of different echelons in making better decisions.

The structure of the paper is as follows: the first section consists of a brief literature review of supply chain disruption management, BSC measurement, fuzzy AHP method, also intuitionistic fuzzy and Decision Process by Choquet integral Operator. Research methodology is explained in Section 2 and data analysis and case results are discussed afterwards in Section 3. Finally, last section concludes the paper, including suggestions for further research.

\section{Literature review}

\subsection{Disruption management in supply chain}

The issue of supply chain management combining sustainability and resilience has been receiving more attention and this cannot come true unless consideration of disruption risks (Azadi et al. 2015). Supply chain disruption management has turned out to be vital for many companies (Chen, Xiao 2015). Changes in the environment, complexity and vulnerability of supply chains make the companies more ready for potential disruptions (Revilla, Sáenz 2014).

\footnotetext{
${ }^{1}$ Energy Information Administration.
} 
There are different scholars who tried to define disruption in supply chain. Schmidt and Raman (2012) defined it as an event that is unplanned and adversely affects corporate's ordinary operations (Schmidt, Raman 2012). Actually, disruption is a category of risk and causes new challenges for supply chain managers who encounter the ripple effect because of structural disruptions. The ripple effect determines the impact of a disruption on supply chain performance and the disruption-based domain of changes in the supply chain structures. Managing the ripple effect is closely related to designing and planning robust resilient supply chains (Ivanov et al. 2016b). In other words, risk is the relationship between some possible negative outcomes, while the disruption is the corresponding probabilities for each issue. Thus, supply chain risk management attempts to predict, interpret and avert unpleasant effects of any disruption in a supply chain (Rangel et al. 2015). Natural disaster, labor dispute, supply bankruptcy, war and terrorism, supply monopolism as well as capacity and responsiveness of alternative suppliers can be determined as disruption drivers in the supply chain based on Chopra and Sodhi study (Chopra, Sodhi 2004). Other scholars' studies about disruption management in supply chain are determined in Table 1. Events such as the terrorist attacks on September 11th, the devastation of New Orleans after hurricane Katrina, and the tsunami in Thailand and India are extensions to this matter (Vakharia, Yenipazarli 2009). There are also several studies which reflect this reality that disruption in the supply chain can lead to a negative financial and nonfinancial impact on the firm and industry performance. For instance, Mostly outcomes of disruptive events in the supply chain as a whole can be mentioned as margin erosion, sudden demand change, physical product flow disruption, product quality failure, social responsibility failure, failure to comply with law and lack of employee safety (Dobie 2015).

Table 1. Literature review of disruption management in supply chain as a whole

\begin{tabular}{lll}
\hline Year & \multicolumn{1}{c}{ Scholar } & \multicolumn{1}{c}{ Overall scope of the study } \\
\hline $2000 \begin{array}{l}\text { (Applequist } \\
\text { et al. 2000) }\end{array}$ & $\begin{array}{l}\text { Determination of measures for performance evaluation of supply chain } \\
\text { projects with specified risks }\end{array}$ \\
\hline $\begin{array}{l}\text { (Johnson } \\
2001)\end{array}$ & Review of experiences related to risk management in toy supply chain \\
\cline { 2 - 3 } & $\begin{array}{l}\text { (Sheffi 2001) } \\
\text { Paying attention to the fact that investments and reorganization of its } \\
\text { supply chain needs to be prepared for terrorist attacks }\end{array}$ \\
\hline $\begin{array}{l}\text { (Mitroff, } \\
\text { Alpaslan }\end{array}$ & Guidelines for preparedness activities with internal threats \\
$\begin{array}{ll}\text { (Rice, } \\
\text { Caniato } \\
2003)\end{array}$ & $\begin{array}{l}\text { Study on the need of supply chains to address the security and resilience } \\
\text { and also offering solutions to increase these matters }\end{array}$ \\
\hline $\begin{array}{l}\text { (Zsidisin, } \\
\text { Ellram 2003) }\end{array}$ & $\begin{array}{l}\text { Examining the impact of risks within the supply chain and ways to deal } \\
\text { with these risks }\end{array}$ \\
\hline
\end{tabular}


Continue of Table 1

\begin{tabular}{|c|c|c|}
\hline Year & Scholar & Overall scope of the study \\
\hline \multirow{4}{*}{2004} & $\begin{array}{l}\text { (Cavinato } \\
\text { 2004) }\end{array}$ & $\begin{array}{l}\text { Discussion on definitions of risk concept and focusing on logistics risks in } \\
\text { the supply chain }\end{array}$ \\
\hline & $\begin{array}{l}\text { (Chopra, } \\
\text { Sodhi 2004) }\end{array}$ & $\begin{array}{l}\text { Classification of supply chain risks, their drivers and strategies to deal with } \\
\text { them }\end{array}$ \\
\hline & (Finch 2004) & $\begin{array}{l}\text { Presentation of a secondary analysis of the literature, supplemented by } \\
\text { case studies. Risk identification, risk analysis, risk reduction-transfer and } \\
\text { acceptance and risk monitoring are considered for disruption management }\end{array}$ \\
\hline & $\begin{array}{l}\text { (Hallikas } \\
\text { et al. 2004) }\end{array}$ & $\begin{array}{l}\text { Study on the general process of risk management for supplier } \\
\text { networks considering collective response planning and qualitative } \\
\text { probability estimation. Risk identification, risk assessment, decision and } \\
\text { implementation of risk management actions and risk monitoring are the } \\
\text { steps which are considered for handling disruptions }\end{array}$ \\
\hline \multirow{3}{*}{2005} & $\begin{array}{l}\text { (Kleindorfer, } \\
\text { Saad 2005) }\end{array}$ & $\begin{array}{l}\text { Expansion of a conceptual framework for managing risk and disruption, } \\
\text { including the criteria of evaluation and reduction }\end{array}$ \\
\hline & (Peck 2005) & $\begin{array}{l}\text { Introduction of a conceptual framework for understanding the vulnerability } \\
\text { of the supply chain and discussing the drivers of vulnerability }\end{array}$ \\
\hline & $\begin{array}{l}\text { (Sheffi, Rice } \\
\text { 2005) }\end{array}$ & $\begin{array}{l}\text { Discussing the disruption and providing guidance to improve supply chain } \\
\text { flexibility }\end{array}$ \\
\hline 2006 & $\begin{array}{l}\text { (Tomlin } \\
2006)\end{array}$ & $\begin{array}{l}\text { Presentation of the model for investigation of the impact of different } \\
\text { strategies for reducing disruption such as cooperation with different } \\
\text { supplier }\end{array}$ \\
\hline 2007 & $\begin{array}{l}\text { (Adhitya } \\
\text { et al. 2007) }\end{array}$ & $\begin{array}{l}\text { Detection Time, disrupted Object and disruption duration are considered } \\
\text { as disruption features and matters such as key performance indicators, } \\
\text { monitoring and coordination are considered for running management } \\
\text { functions after the outbreak of disruption }\end{array}$ \\
\hline \multirow[b]{2}{*}{2008} & $\begin{array}{l}\text { (Azaron } \\
\text { et al. 2008) }\end{array}$ & $\begin{array}{l}\text { Consideration of production, supply and transportation disruption based on } \\
\text { capacity approach and stochastic programming }\end{array}$ \\
\hline & $\begin{array}{l}\text { (Manuj, } \\
\text { Mentzer } \\
\text { 2008) }\end{array}$ & $\begin{array}{l}\text { Providing visions about the applicability of six risk management strategies } \\
\text { based on environmental conditions and the role of three moderators. } \\
\text { Steps such as risk identification, risk assessment and evaluation, risk } \\
\text { management, strategy selection, implementation of supply chain risk } \\
\text { management strategy and mitigation of supply chain risks are considered } \\
\text { for management functions before the outbreak of disruption with the focus } \\
\text { of prevention of disruption emergence }\end{array}$ \\
\hline \multirow[b]{2}{*}{2009} & $\begin{array}{l}\text { (Bakshi, } \\
\text { Kleindorfer } \\
\text { 2009) }\end{array}$ & $\begin{array}{l}\text { The division of disruption risk management strategies, development of } \\
\text { methods for disruption management in supply chain }\end{array}$ \\
\hline & $\begin{array}{l}\text { (Oehmen } \\
\text { et al. 2009) }\end{array}$ & $\begin{array}{l}\text { By consideration of disruptions related to location and steps of risk } \\
\text { identification, risk assessment, risk mitigation, a supply chain risk structure } \\
\text { model is proposed to describe the system that determines the causes and } \\
\text { effects of supply chain risks and also the supply chain risk dynamics model }\end{array}$ \\
\hline 2011 & $\begin{array}{l}\text { (Vahdani } \\
\text { et al. 2011) }\end{array}$ & $\begin{array}{l}\text { Investigation of production and supply disruptions from the perspective of } \\
\text { inventory management based on simulation and control theory }\end{array}$ \\
\hline
\end{tabular}


End of Table 1

\begin{tabular}{|c|c|c|}
\hline Year & Scholar & Overall scope of the study \\
\hline \multirow{3}{*}{2013} & $\begin{array}{l}\text { (Rafiei et al. } \\
\text { 2013) }\end{array}$ & $\begin{array}{l}\text { Reliability of multi product supply chain design } \\
\text { considering multi period with facility disruption }\end{array}$ \\
\hline & $\begin{array}{l}\text { (Lim et al. } \\
\text { 2013) }\end{array}$ & $\begin{array}{l}\text { Backup suppliers and their effect on production and supply disruption } \\
\text { considering mixed integer programming }\end{array}$ \\
\hline & $\begin{array}{l}\text { (Behdani } \\
\text { 2013) }\end{array}$ & $\begin{array}{l}\text { Development of a systematic framework for handling disruptions in supply } \\
\text { chains and also a modelling approach to support the decision-making } \\
\text { process in handling supply chain disruptions based on simulation technique }\end{array}$ \\
\hline \multirow{2}{*}{2014} & $\begin{array}{l}\text { (Paul et al. } \\
\text { 2014) }\end{array}$ & $\begin{array}{l}\text { Consideration of production, supply and transportation disruptions based on } \\
\text { inventory management principles by simulation and control theory }\end{array}$ \\
\hline & $\begin{array}{l}\text { (Ivanov } \\
\text { et al. 2014) }\end{array}$ & $\begin{array}{l}\text { Consideration of production, supply and transportation disruptions from } \\
\text { capacity and multiple supplier perspective }\end{array}$ \\
\hline \multirow[b]{2}{*}{2016} & $\begin{array}{l}\text { (Ivanov } \\
\text { et al. 2016a) }\end{array}$ & Literature review of disruptions in supply chains and recovery policies \\
\hline & $\begin{array}{l}\text { (Jabbarzadeh } \\
\text { et al. 2016) }\end{array}$ & $\begin{array}{l}\text { Presentation of a hybrid robust-stochastic optimization model and a } \\
\text { Lagrangian relaxation solution method for designing a supply chain which } \\
\text { is resilient to supply/demand interruptions and also facility disruptions }\end{array}$ \\
\hline \multirow{4}{*}{2017} & $\begin{array}{l}\text { (Paul et al. } \\
\text { 2017) }\end{array}$ & $\begin{array}{l}\text { Extension of a quantitative model for disruption mitigation in a three stage } \\
\text { supply chain with development of a fuzzy inference system (FIS) tool to } \\
\text { predict the changes in future demand }\end{array}$ \\
\hline & $\begin{array}{l}\text { (Schmitt } \\
\text { et al. 2017) }\end{array}$ & $\begin{array}{l}\text { Pointed to this matter that the dynamic policies from incorporating a meta } \\
\text { heuristic parameter search over multiple echelons have their own benefits } \\
\text { while studying disruptions in a multi-echelon supply chain }\end{array}$ \\
\hline & $\begin{array}{l}\text { (Giri, Sarker } \\
\text { 2017) }\end{array}$ & $\begin{array}{l}\text { Studying about improving the performance of a supply chain consisting } \\
\text { of a monopolistic manufacturer, a third party logistics service provider } \\
\text { and multiple independent retailers through coordination under production } \\
\text { disruption }\end{array}$ \\
\hline & $\begin{array}{l}\text { (Ivanov } \\
\text { et al. 2017) }\end{array}$ & $\begin{array}{l}\text { Comparing the performance impact of different recovery policies on return } \\
\text { flows based on the simultaneously optimized re-configuration plans for } \\
\text { material flows }\end{array}$ \\
\hline
\end{tabular}

So, the essence of disruption management in today's supply chains has forced managers to think about different strategies (Ratzmann et al. 2016). A good strategy should have capabilities of identifying risk for the whole life cycle; prediction of the financial impact of the disruptions and proposing solutions for its reduction while considering different parts of supply chain (Kiser, Cantrell 2006). Some recent strategies which are under consideration by different managers for risk mitigation are as such (Tang 2006; Ivanov et al. 2016b):

- Segmentation of suppliers according to disruption risks;

- Optimization of inventory management;

- Segmentation of production plants according to disruption risks; 
- Enhancement of manufacturing process and capacity flexibility;

- Consideration of approaches such as postponed differentiation in production;

- Increase transportation process and capacity flexibility;

- Creation of supply chain visibility;

- Leveraging technology and social media;

- Prioritization and allocation of resources according to risk considerations;

- Revenue management by controlling product demand;

- Increase control of product exposure to customers.

Some of the previous studies related to disruption management in petroleum supply chain are presented in Table 2 for more clarification.

Table 2. Some of studies related to disruption management in petroleum supply chain

\begin{tabular}{lll}
\hline Year & \multicolumn{1}{c}{ Scholar } & \multicolumn{1}{c}{ Overall scope of the study } \\
\hline 2009 & (Kean 2009) & $\begin{array}{l}\text { Investigation of the Department of Defence requirements for } \\
\text { petroleum disruption management as a response system }\end{array}$ \\
\hline 2009 & (Yeletaysi 2009) & $\begin{array}{l}\text { Development of a framework to explore and quantify risk of } \\
\text { disruptions in the U.S. petroleum supply chain caused by hurricanes } \\
\text { using GIS and simulation technique }\end{array}$ \\
\hline 2011 & (Katata 2011) & $\begin{array}{l}\text { Consideration of supply disruption risks and robust investment } \\
\text { strategies in petroleum markets based on modelling oil and gas } \\
\text { supply disruption risks, and robust portfolio management }\end{array}$ \\
\hline 2015 & (de Barros, & $\begin{array}{l}\text { Development and application of a methodology to assess the } \\
\text { capacity of petroleum refineries to point to unforeseen ethanol } \\
\text { supply disruption in the short term. The tool utilized is a mixed- } \\
\text { integer linear programming model }\end{array}$ \\
\hline 2015 & Szklo 2015) & $\begin{array}{l}\text { Proposing a deterministic mixed integer linear programming } \\
\text { model for downstream petroleum supply chain with the aid of } \\
\text { distinguishing the optimal distribution centre locations, capacities, } \\
\text { transportation modes and transfer volumes in order to make supply } \\
\text { chain less vulnerable to disruptions }\end{array}$ \\
\hline Szmerekovsky & 2015) & $\begin{array}{l}\text { Proposing a Markov decision process model for determination of } \\
\text { desirable sizes and policies of a strategic petroleum reserve to cope } \\
\text { with related disruptions }\end{array}$ \\
\hline 2016 & (Bai et al. 2016 & $\begin{array}{l}\text { Investigation of the disruption management strategies from shortage } \\
\text { supply perspective }\end{array}$ \\
\hline 2017 & (Officials 2006 & $\begin{array}{l}\text { Consideration of supply disruptions in petroleum industry and the } \\
\text { robust counterpart of the portfolio management problem }\end{array}$ \\
\hline 2014) & &
\end{tabular}

\section{2. $\mathrm{BSC}$ in the measurement and evaluation}

The Balanced Score Card (BSC) is a useful method in strategic management, used widely in business and industry, government, and non-profit organizations to adjust business activities to the vision and strategy of the organization. Taking into account the main elements in the process of policy making as formation, implementation and evaluation and also consideration of a variety of models that have been introduced in 
this regard, BSC has been known as a comprehensive model for organizing the entire process of organizational policy. BSC tries to make a balance among these domains:

- The balance between financial and non-financial metrics;

- The balance between internal and external stakeholders of the organization;

- The balance between short-term goals and long-term ones;

- The balance between lead indicators (prospective) and function (retrospective).

$\mathrm{BSC}$ reveals the importance of non-financial measures in organizations and put them in a comprehensive measurement system for performance evaluation. Consideration of non-financial measures such as ability to retain customers, displacement of human resources or the number of new products can be helpful in determination of more realistic organizational strategies (Norton, Kaplan 1993; Letza 1996; Yeniyurt 2003).

In this study, the conventional measure of BSC model have been used as decision criteria in AHP model, while AHP itself is used for determination of fuzzy measures.

\subsection{Fuzzy AHP method}

Fuzzy $\mathrm{AHP}^{2}$ is prone to be a very useful methodology for multiple criteria decisionmaking in fuzzy environments. It is a method which can handle the vagueness of experts' opinions and is used when the relationships among criteria are hierarchical. It should be mentioned that $\mathrm{ANP}^{3}$ technique should be used when the network structure between criteria are observable (Wang, Chin 2011).

In this systematic approach, pair-wise comparisons in the judgment matrix are done by use of fuzzy numbers, fuzzy arithmetic and fuzzy aggregation operators. This procedure is performed to specify a sequence of weight vectors. Main steps of fuzzy AHP method are as below (Güngör et al. 2009):

Step 1. In the first step, the network structure of the assessment problem should be developed. It becomes clear that the assessment of alternatives such as strategies should be done based on which criteria.

Step 2. Now, decision makers have to determine the relative weights of each alternative. The weights are determined under pair-wise comparison between each pair of criteria using a fuzzy preference scale.

Step 3. After setting up the network and pair-wise comparisons of criteria of alternatives, global value of priority of alternatives should be calculated.

\subsection{Intuitionistic fuzzy sets (IFS)}

Intuitionistic fuzzy sets are found to be highly useful to deal with vagueness since there are situations in which evaluation of membership values is not possible. Based on the same reason it is clear that determination of non-membership function is not always possible too. That is why fuzzy sets theory is not suitable in this situations. The problems which are related to fuzzy set theory can be well dealt with IFS theory too, while

\footnotetext{
2 Analytical Hierarchy Process.

${ }^{3}$ Analytical Network Process.
} 
IFS theory is more appropriate to deal with some complicated problems than fuzzy set theory (Paul et al. 2017).

Attansov presented this extension of fuzzy sets in 1986. Each element in IFS is shown by an ordered pair and each ordered pair is defined through a membership degree and non-membership degree. The sum of these degree values must be less than or equal to unity. Considering a fixed set $X=\left\{x_{1}, x_{2}, \ldots, x_{n}\right\}$, an IFS is defined as (Xu 2010; Hao et al. 2017):

$$
A=\left\{\left\langle x_{i}, t_{A}\left(x_{i}\right), f_{A}\left(x_{i}\right)\right\rangle \mid x_{i} \in X\right\},
$$

where $t_{A}\left(x_{i}\right)$ is referring to membership degree and $f_{A}\left(x_{i}\right)$ determines non-membership degree for each $x_{i}$. Obviously this condition should be met for all of the $x_{i}$ :

$$
0 \leq t_{A}\left(x_{i}\right)+f_{A}\left(x_{i}\right) \leq 1 .
$$

So, as a whole an ordered pair can be considered as an IFS value if it could meet the following condition:

$$
t_{\alpha}\left(x_{i}\right) \in[0,1], f_{\alpha}\left(x_{i}\right) \in[0,1], 0 \leq t_{\alpha}\left(x_{i}\right)+f_{\alpha}\left(x_{i}\right) \leq 1 .
$$

Some useful operations for each two IFS values like

$$
\begin{gathered}
\alpha\left(x_{i}\right)=\left(t_{\alpha}\left(x_{i}\right), f_{\alpha}\left(x_{i}\right)\right), \alpha\left(x_{j}\right)=\left(t_{\alpha}\left(x_{j}\right), f_{\alpha}\left(x_{j}\right)\right) \text { can be as such: } \\
\alpha\left(x_{i}\right) \oplus \alpha\left(x_{j}\right)=\left(t_{\alpha}\left(x_{i}\right)+t_{\alpha}\left(x_{j}\right)-t_{\alpha}\left(x_{i}\right) * t_{\alpha}\left(x_{j}\right), f_{\alpha}\left(x_{i}\right) * f_{\alpha}\left(x_{j}\right)\right) ; \\
\alpha\left(x_{i}\right) \otimes \alpha\left(x_{j}\right)=\left(t_{\alpha}\left(x_{i}\right) * t_{\alpha}\left(x_{j}\right), f_{\alpha}\left(x_{i}\right)+f_{\alpha}\left(x_{j}\right)-f_{\alpha}\left(x_{i}\right) * f_{\alpha}\left(x_{j}\right)\right) ; \\
\lambda \alpha\left(x_{i}\right)=\left(1-\left(1-t_{\alpha}\left(x_{i}\right)\right)^{\lambda} * t_{\alpha}\left(x_{j}\right),\left(f_{\alpha}\left(x_{i}\right)\right)^{\lambda}\right), \quad \lambda \succ 0 ; \\
\left(\alpha\left(x_{i}\right)\right)^{\lambda}=\left(\left(t_{\alpha}\left(x_{i}\right)\right)^{\lambda}, 1-\left(1-\left(f_{\alpha}\left(x_{i}\right)\right)^{\lambda}\right), \quad \lambda \succ 0 .\right.
\end{gathered}
$$

For comparing each two IFS values, the score degree of each value should be determined as $s\left(\alpha\left(x_{i}\right)\right)=t_{\alpha}\left(x_{i}\right)-f_{\alpha}\left(x_{i}\right), s\left(\alpha\left(x_{j}\right)\right)=t_{\alpha}\left(x_{j}\right)-f_{\alpha}\left(x_{j}\right)$ and the accuracy degree should be specified through $h\left(\alpha\left(x_{i}\right)\right)=t_{\alpha}\left(x_{i}\right)+f_{\alpha}\left(x_{i}\right), h\left(\alpha\left(x_{j}\right)\right)=t_{\alpha}\left(x_{j}\right)+f_{\alpha}\left(x_{j}\right)$. Then the ranking method for IFSs should be as such:

If $s\left(\alpha\left(x_{i}\right)\right) \succ s\left(\alpha\left(x_{j}\right)\right)$, then IFS1 is larger than IFS2;

If $s\left(\alpha\left(x_{i}\right)\right)=s\left(\alpha\left(x_{j}\right)\right)$, then the following comparison should be done:

If $h\left(\alpha\left(x_{i}\right)\right)=h\left(\alpha\left(x_{j}\right)\right)$, then both IFSs are equal,

If $h\left(\alpha\left(x_{i}\right)\right) \succ h\left(\alpha\left(x_{j}\right)\right)$, then IFS1 is larger than IFS2,

If $h\left(\alpha\left(x_{i}\right)\right) \prec h\left(\alpha\left(x_{j}\right)\right)$, then IFS1 is smaller than IFS2.

\subsection{Decision process by IFS choquet integral operator}

Choquet integral operator in companion with intuitionistic fuzzy sets can be a useful method in decision making process. When in 1974, Sugeno defined new fuzzy measure (non-additive measure), the need of criteria independency in decision problems was resolved. Since then, Choquet integral operator which is based on fuzzy measure got special attentions. 
Steps of IFS Choquet integral operator are not complicated. First of all, the partial evaluation of the alternative $a_{i}, i=1, \ldots, n$ should be made via intuitionistic fuzzy value to shape a decision making matrix as below:

$$
R=\left(\begin{array}{cccc}
\tilde{a}_{11} & \tilde{a}_{12} & \ldots & \tilde{a}_{1 m} \\
\tilde{a}_{21} & \tilde{a}_{21} & \ldots & \tilde{a}_{2 m} \\
\ldots & \ldots & \ldots & \ldots \\
\tilde{a}_{n 1} & \tilde{a}_{n 2} & \ldots & \tilde{a}_{n m}
\end{array}\right), \quad \tilde{a}_{i j}=\left(t_{i j}, f_{i j}\right), \quad i=1,2, \ldots, n ; j=1,2, \ldots, n .
$$

After that, the ranks of partial evaluation $\tilde{a}_{i j}$ should be determined via calculation of $s\left(\tilde{a}_{i j}\right)$ and $h\left(\tilde{a}_{i j}\right)$. So, the partial evaluation $\tilde{a}_{i j}$ of the alternative $a_{i}$ is done in a way that $\tilde{a}_{i, j} \leq \tilde{a}_{i, j+1}$.

In the next step and after evaluation of alternatives by experts, fuzzy measures should be specified. In the Choquet integral model, where criteria can be dependent, a fuzzy measure is applied to define a weight on each combination of criteria, so that makes it possible to model the interactions existing among criteria. Since the calculation of fuzzy measure is not easy, different ways have been proposed from various scholars in literature as like as use of the results of methods such as AHP technique and the rational weights.

At last, the Choquet integral operator should be used to aggregate all $\tilde{a}_{i j}=\left(t_{i j}, f_{i j}\right)$ in $\mathrm{i}^{\text {th }}$ row of the intuitionistic fuzzy decision matrix into total values of $\tilde{a}_{i}=\left(t_{\tilde{a}_{i}}, f_{\tilde{a}_{i}}\right)$ :

$$
\operatorname{IFC}_{\mu}\left(\tilde{a}_{i 1}, \ldots, \tilde{a}_{i n}\right)=\left(1-\prod_{j=1}^{n}\left(1-t_{\tilde{a}_{i(j)}}\right)^{\mu\left(A_{(j)}\right)-\mu\left(A_{(j+1)}\right)}, \prod_{j=1}^{n}\left(f_{\tilde{a}_{i(j)}}\right)^{\mu\left(A_{(j)}\right)-\mu\left(A_{(j+1)}\right)}\right) .
$$

Now, according to the total values of $\tilde{a}_{i}=\left(t_{\tilde{a}_{i}}, f_{\tilde{a}_{i}}\right)$ and via calculation of score degree $s\left(\tilde{a}_{i}\right)$ and accuracy degree $h\left(\tilde{a}_{i}\right)$, all the alternatives $a_{i}$ can be ranked and the decision making process is completed (Tan, Chen 2010).

\section{Research methodology}

The aim of this paper as previously said is to identify and prioritize the strategies related to disruption management in petroleum supply chain. For this reason, a suitable set of criteria for prioritizing strategies are determined at the first step. This is done since the criteria are unique in each industry. Then by asking 32 high and mid-level managers in different parts of studied supply chain and the use of T-test, the most important criteria were chosen. The number of this sample is the minimum possible number of Normal sample because of managers' busy schedule which had to be considered. Although factor analysis method is more suitable to assess the priorities of criteria, due to the impossibility of taking samples with a high number and considering the limitations and sensitivity of the information of the competitive market of petroleum products, T-test method is performed. The weights of these criteria are specified via application of AHP technique. 
In the second step, after the literature review and interviews with industry experts, academics and supply chain managers, disruption management strategies for the petroleum industry are determined. The priorities of the strategies are determined through combination of Choquet integral operator and AHP. The main steps of this study are shown in Figure 1.

Based on the importance, a petroleum supply chain is considered to be studied in this paper. General activities of this supply chain are depicted in Figure 2. Paying attention to the type of product, all or some these activities can be implemented.

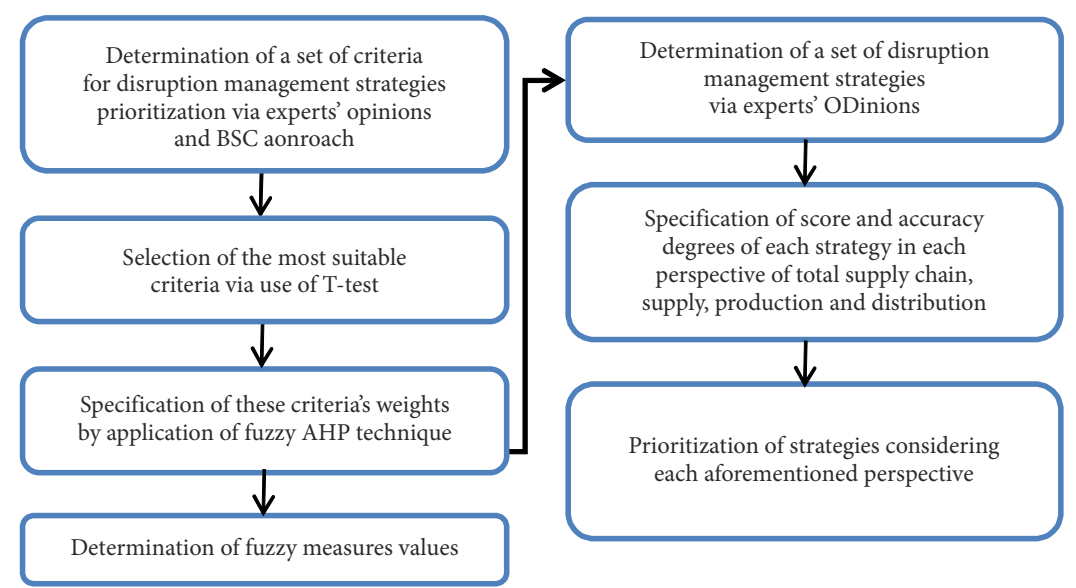

Fig. 1. Main steps of this study

\section{Petroleum Supply Chain}
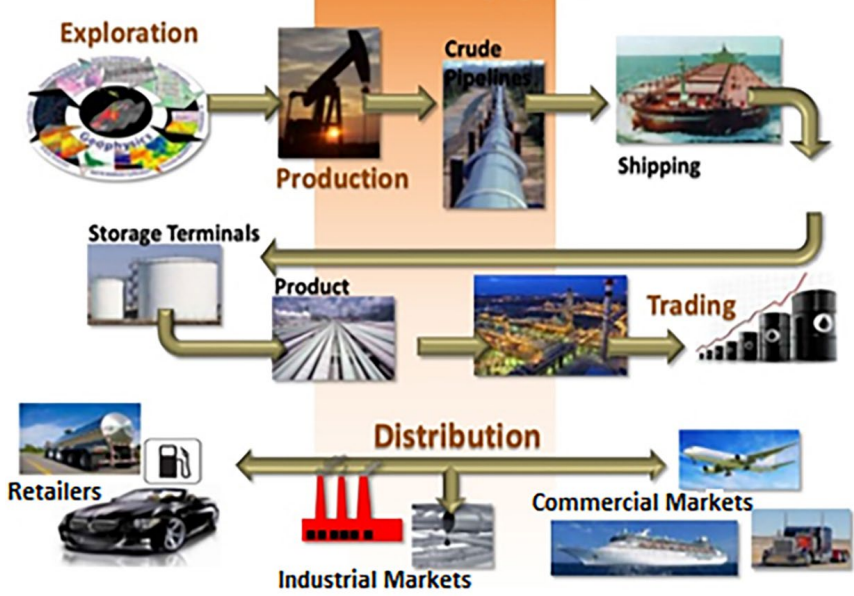

Fig. 2. Petroleum supply chain (WKP 2015) 
The studied supply chain is a real world supply chain in Iran, which supplies some of its needed material from abroad by maritime and road transport. Products are maintained in distribution centres in different parts of the country and sent to retailers according to regional needs. Final customers are in direct relationship with these retailers. In each part of the supply chain shown in Figure 2, from supplier, maritime and road transport to production process and transferring to distributors or retailers, there can be special disruptions. Some kinds of these disruptions and criteria to investigate them can be determined through literature review and others should be gained based on consulting industry experts.

At first, a list of member companies of the studied petroleum supply chain, including suppliers and customers of the final products is provided to collect research data. A questionnaire containing criteria for making investigations about disruptions are distributed among 54 senior managers of Iran petroleum supply chain in purchasing, sales, finance and production companies. Managers are asked to determine the importance of each criterion for evaluation of petroleum supply chain disruptions. By consideration of Cochran's sample size formula for population of 74 managers working in the studied supply chain and taking 95\% confidence level and 7\% error level, 54 managers from whole SC are selected randomly.

Validity of this questionnaire is determined considering matters such as customers' satisfaction, profitability and product development which are referred to in BSC approach and are widely used. Reliability of the questionnaire is specified through Cronbach alpha by SPSS software. The alpha value is 0.748 which can be interpreted suitable.

Now by consideration of value of paying attention to this matter that criteria with the importance level more than average should be determined, statistical hypothesis (H0: $\mu>3$ ) is used. The criteria and results of statistical hypothesis are shown in Table 3 . As is obvious, six criteria of "deviation from the production plan", "Innovation and education capita", "profitability", "new product development", "customer satisfaction" and "return on investment" are selected in this step as prioritizing criteria in AHP section.

The weights of criteria are presented in Table 4. As is clear, these weights are determined based on four main perspectives of total supply chain, supply, production and distribution. In this way and via use of these weights, we can specify fuzzy measures from these important perspectives of supply chain management. Since the weights of criteria are only used in determination of fuzzy measures, the final results of AHP method are presented in this section.

Now, the fuzzy measures of these criteria can be determined by use of the specified weights. Fuzzy measure of each subset of criteria in different perspectives can be calculated by summing up the weights of that criteria reported in Table 4.

Strategies can be prioritized after determination of fuzzy measures. It should be mentioned that the strategies are determined based on literature review and structured interviews with experts in petroleum industry and supply chain professors. 19 of the most important strategies have been determined as follows. See the strategies' descriptions in Table 5. How to determine the priority of strategies is outlined in this section and after that, the strategies are more discussed in Section 3. 
The rank of each strategy in each perspective of "total supply chain", "production", "supply" and "distribution" has been specified for making more clarification about each strategy's role in each aspect of supply chain functions.

IFVs decision matrix of 19 strategies based on 6 specified criteria is determined considering each of 4 aforementioned perspectives. IFVs decision matrix of strategies in each perspective is determined reordered via comparison of their score and accuracy degrees. At last, their overall values $\left(\tilde{a}_{i}\right)$ are calculated via using the intuitionistic fuzzy choquet integral operator. Reordered decision matrix and overall values $\left(\tilde{a}_{i}\right)$ of strategies in total supply chain perspective are shown in Table 6 .

Table 3. Results of T-test for selection of criteria related to disruption strategies' evaluation

\begin{tabular}{llccccc}
\hline \multicolumn{1}{c}{ Criteria } & $\mathrm{t}$-value & Degree of freedom & Sig. & Lower limit & Upper limit \\
\hline 1 & Production rate & -3.088 & 31 & 0.004 & -0.8302 & -0.1698 \\
\hline 2 & Inventory turnover & -2.252 & 31 & 0.032 & -0.7346 & -0.0354 \\
\hline 3 & $\begin{array}{l}\text { After-sales service } \\
\text { management }\end{array}$ & -2.523 & 31 & 0.017 & -0.2265 & 0.6015 \\
\hline 4 & $\begin{array}{l}\text { Deviation from the } \\
\text { production plan }\end{array}$ & 0.924 & 31 & $0.363^{*}$ & -0.9109 & -0.3391 \\
\hline 5 & Market identifying & -4.458 & 31 & 0 & -0.2539 & 0.3789 \\
\hline 6 & Profitability & 0.403 & 31 & $0.69^{*}$ & -0.4474 & 0.1349 \\
\hline 7 & $\begin{array}{l}\text { Innovation and education } \\
\text { capita }\end{array}$ & -1.094 & 31 & $0.282^{*}$ & -0.7487 & -0.1545 \\
\hline 8 & $\begin{array}{l}\text { Information system } \\
\text { quality }\end{array}$ & -3.105 & 30 & 0.004 & -0.452 & 0.202 \\
\hline 9 & Customer satisfaction & -0.78 & 31 & $0.442^{*}$ & -0.2544 & 0.5669 \\
\hline 10 & $\begin{array}{l}\text { New product } \\
\text { development }\end{array}$ & 0.776 & 31 & $0.444^{*}$ & -0.6609 & -0.0891 \\
\hline 11 & $\begin{array}{l}\text { Satisfaction of human } \\
\text { resources }\end{array}$ & -2.675 & 31 & 0.012 & -0.282 & 0.532 \\
\hline 12 & Return on Investment & 0.626 & 31 & $0.536^{*}$ & -0.2265 & 0.6015 \\
\hline
\end{tabular}

Table 4. The weights of criteria related to strategies selection from different perspectives

\begin{tabular}{|c|c|c|c|c|c|c|}
\hline \multirow{2}{*}{ Criteria } & \multirow{2}{*}{\multicolumn{2}{|c|}{ Sub-criteria }} & \multicolumn{4}{|c|}{ Weights } \\
\hline & & & Total supply chain & Supply & Production & Distribution \\
\hline \multirow{2}{*}{ Financial } & $\mathrm{C} 1$ & Profitability & 0.468 & 0.561 & 0.302 & 0.115 \\
\hline & $\mathrm{C} 2$ & Return on Investment & 0.156 & 0.145 & 0.184 & 0.031 \\
\hline Customer & $\mathrm{C} 3$ & Customer satisfaction & 0.196 & 0.031 & 0.201 & 0.432 \\
\hline \multirow{2}{*}{$\begin{array}{l}\text { Internal } \\
\text { processes }\end{array}$} & $\mathrm{C} 4$ & $\begin{array}{l}\text { Deviation from the } \\
\text { production plan }\end{array}$ & 0.104 & 0.203 & 0.022 & 0.101 \\
\hline & $\mathrm{C} 5$ & New product development & 0.026 & 0.023 & 0.11 & 0.2 \\
\hline $\begin{array}{l}\text { Growth and } \\
\text { learning }\end{array}$ & $\mathrm{C} 6$ & $\begin{array}{l}\text { Innovation and education } \\
\text { capita }\end{array}$ & 0.05 & 0.037 & 0.181 & 0.121 \\
\hline
\end{tabular}


Table 5. Brief definition of each strategy

\begin{tabular}{|c|c|c|c|}
\hline & Strategy & Definition & Source \\
\hline S1 & $\begin{array}{l}\text { Increase } \\
\text { transparency and } \\
\text { coordination }\end{array}$ & $\begin{array}{l}\text { A disruption in supply chain is usually shared, so } \\
\text { vertical and horizontal coordination can help to } \\
\text { decrease effects or even predict the occurrence. }\end{array}$ & (Gao 2015) \\
\hline $\mathrm{S} 2$ & $\begin{array}{l}\text { The use of } \\
\text { insurance } \\
\text { for premium } \\
\text { compensation }\end{array}$ & $\begin{array}{l}\text { Purchasing insurance for facilities, components and } \\
\text { any parts of supply chain, although cannot decrease } \\
\text { disruption but can compensate some losses. }\end{array}$ & $\begin{array}{l}\text { (Li, Wang } \\
\text { 2015) }\end{array}$ \\
\hline $\mathrm{S} 3$ & $\begin{array}{l}\text { Flexible } \\
\text { transportation }\end{array}$ & $\begin{array}{l}\text { Supply chains should be able to use multimodal } \\
\text { transportation, especially international companies. }\end{array}$ & $\begin{array}{l}\text { (Martha, } \\
\text { Vratimos 2002) }\end{array}$ \\
\hline S4 & $\begin{array}{l}\text { Safety stock } \\
\text { of critical } \\
\text { components }\end{array}$ & $\begin{array}{l}\text { Safety stock of critical components can be hold by } \\
\text { limited investment. }\end{array}$ & $\begin{array}{l}\text { (Sheffi, Rice } \\
\text { 2005; Ivanov } \\
\text { et al. 2017) }\end{array}$ \\
\hline S5 & $\begin{array}{l}\text { Supply chain } \\
\text { security } \\
\text { management }\end{array}$ & $\begin{array}{l}\text { It can prevent manmade disruptions like fire, network } \\
\text { hacking, etc. }\end{array}$ & $\begin{array}{l}\text { (Park et al. } \\
\text { 2016) }\end{array}$ \\
\hline S6 & $\begin{array}{l}\text { Influencing the } \\
\text { customer's choice }\end{array}$ & $\begin{array}{l}\text { Motivating customers to buy what company wants is } \\
\text { always important. Dell in Taiwan earthquake in } 1999 \\
\text { could successfully manage customers to buy available } \\
\text { products instead of their choice by different discounts. }\end{array}$ & $\begin{array}{l}\text { (Birkie et al. } \\
\text { 2014) }\end{array}$ \\
\hline S7 & $\begin{array}{l}\text { Keep track of } \\
\text { weather forecasts }\end{array}$ & $\begin{array}{l}\text { Experience of successful companies like Toyota } \\
\text { shows that monitoring weather forecast can decrease } \\
\text { effects of disruption. In } 1999 \text { a snowstorm disrupted } \\
\text { production at Ford Motor Company, Toyota's plants } \\
\text { were uninterrupted. }\end{array}$ & (Murphy 2006) \\
\hline S8 & $\begin{array}{l}\text { Redesign of } \\
\text { products with } \\
\text { risk-sharing } \\
\text { approach }\end{array}$ & $\begin{array}{l}\text { Redesign products to use mutual components can help } \\
\text { to satisfy different customers by limited equipment. }\end{array}$ & $\begin{array}{l}\text { (Robles, } \\
\text { Severson 2016) }\end{array}$ \\
\hline S9 & $\begin{array}{l}\text { Increasing the } \\
\text { transparency of } \\
\text { transportation }\end{array}$ & $\begin{array}{l}\text { Sharing information can help to use alternative routes } \\
\text { or facilities. Vehicles can be rerouted and orders can be } \\
\text { changed. }\end{array}$ & $\begin{array}{l}\text { (de Barros, } \\
\text { Szklo 2015) }\end{array}$ \\
\hline $\mathrm{S} 10$ & Multiple sourcing & $\begin{array}{l}\text { Supply monopolies can increase the disruption } \\
\text { consequences. }\end{array}$ & $\begin{array}{l}\text { (Lee, Wolfe } \\
2003)\end{array}$ \\
\hline S11 & $\begin{array}{l}\text { Locating via } \\
\text { consideration of } \\
\text { safety elements }\end{array}$ & $\begin{array}{l}\text { Variety and frequency of disruptions vary in different } \\
\text { locations. Some places are prone to earthquakes, } \\
\text { hurricanes, etc. }\end{array}$ & $\begin{array}{l}\text { (Alexander } \\
1993)\end{array}$ \\
\hline S12 & $\begin{array}{l}\text { Supplier } \\
\text { selection and } \\
\text { capable transport } \\
\text { equipment }\end{array}$ & $\begin{array}{l}\text { Selecting capable suppliers can reduce disruption } \\
\text { effects And as transportation disruptions are } \\
\text { most common kind of events, selecting capable } \\
\text { transportation company or system is too important. }\end{array}$ & $\begin{array}{l}\text { (Hosseini, Al } \\
\text { Khaled 2016) }\end{array}$ \\
\hline S13 & Multiple facilities & $\begin{array}{l}\text { Worldwide dispersion of facilities can decrease } \\
\text { probability of simultaneous disruption and also } \\
\text { disruptions can be compensated by plants in other } \\
\text { locations. }\end{array}$ & $\begin{array}{l}\text { (Simchi-Levi } \\
\text { et al. } 2015 \text { ) }\end{array}$ \\
\hline
\end{tabular}


End of Table 5

Strategy

Definition

Source

Events like changes in customer choices, laws,

S14

Monitoring events technology, etc. might be simple but vital so monitoring (Simchi-Levi

and incidents them and study trends can help in mitigating disruption et al. 2015) effects.

Create a secure Global and decentralized supply chains need more

S15 communications network reliable communication links for coordination and success.

(Park et al. 2016)

S16 Excess inventory Carrying extra inventory can help companies to avoid disruption effects.

(Costantino et al. 2014)

S17 Action against Many disruptions are related to terroristic actions so terrorist threats supply chains can help in this regard as their social (Bueno-Solano, responsibilities as well as a mitigation strategy.

CedilloCampos 2014)

$\mathrm{S} 18$

Standardization of If processes are standard according to disruption in one (Martin, Bell various processes plant, workers in other plants can continue the process. 2016)

Efficient

S19 human resource management Many manmade disruptions are caused by employees, this makes hiring very critical, and also management system can motivate staffs in reducing consequences.

(Coutu 2002)

Table 6. IFVs decision matrix of strategies after reordering and their overall values $\left(\tilde{a}_{i}\right)$ based on total supply chain perspective

\begin{tabular}{|c|c|c|c|c|c|c|c|c|c|c|c|c|c|c|}
\hline & \multicolumn{2}{|c|}{$\mathrm{C} 1$} & \multicolumn{2}{|c|}{$\mathrm{C} 2$} & \multicolumn{2}{|c|}{$\mathrm{C} 3$} & \multicolumn{2}{|c|}{$\mathrm{C} 4$} & \multicolumn{2}{|c|}{$\mathrm{C} 5$} & \multicolumn{2}{|c|}{ C6 } & \multicolumn{2}{|c|}{$\tilde{a}_{i}=\left(t_{\tilde{a}_{i}}, f_{\tilde{a}_{i}}\right)$} \\
\hline $\mathrm{S} 1$ & $(1.00$ & $0.00)$ & $(0.96$ & $0.00)$ & $(0.96$ & 0.04) & $(0.91$ & $0.04)$ & $(0.93$ & $0.07)$ & $(0.91$ & 0.09) & $(1.000$ & $0.000)$ \\
\hline $\mathrm{S} 2$ & $(0.90$ & (29) & .90 & 10) & 89 & $0.11)$ & 0.86 & $0.14)$ & .83 & $0.17)$ & $(0.81$ & 19) & 0 & $0.105)$ \\
\hline S3 & $(0.91$ & 0.09) & $(0.89$ & 1) & 7 & $0.13)$ & 86 & 14) & 84 & $0.16)$ & 81 & ) & $(0.890$ & 000) \\
\hline S4 & $(0.93$ & $0.07)$ & $(0.88$ & $0.10)$ & $(0.81$ & $0.10)$ & $(0.80$ & $0.18)$ & $(0.78$ & $0.22)$ & $(0.76$ & $0.24)$ & 0.866 & $0.096)$ \\
\hline S5 & $(0.91$ & (0.09) & $(0.87$ & $0.13)$ & $(0.83$ & $0.17)$ & $(0.81$ & 0.19) & $(0.69$ & $0.24)$ & $(0.72$ & $0.28)$ & $(0.869$ & $0.127)$ \\
\hline S6 & $(0.90$ & $0.10)$ & $(0.83$ & $0.17)$ & $(0.80$ & $0.20)$ & $(0.72$ & $0.28)$ & $(0.71$ & $0.29)$ & $(0.67$ & $0.33)$ & $(0.849$ & $0.151)$ \\
\hline S7 & $(0.87$ & 0.13) & .79 & 0.13) & 81 & (1) & 72 & $0.23)$ & 72 & $0.28)$ & $(0.71$ & 0.29) & 6 & $0.158)$ \\
\hline S8 & (0.88 & 12) & .83 & $0.14)$ & $(0.84$ & $0.16)$ & $(0.83$ & $0.17)$ & $(0.76$ & $0.24)$ & $(0.73$ & $0.27)$ & (10 & $0.143)$ \\
\hline S9 & $(0.87$ & $0.13)$ & $(0.82$ & $0.18)$ & $(0.81$ & 0.19) & $(0.78$ & $0.22)$ & $(0.73$ & $0.27)$ & $(0.68$ & $0.32)$ & $(0.834$ & $0.166)$ \\
\hline $\mathrm{S} 10$ & $(0.91$ & (0.09) & $(0.90$ & $0.10)$ & $(0.89$ & $0.11)$ & $(0.87$ & $0.13)$ & $(0.79$ & $0.21)$ & $(0.68$ & $0.32)$ & $(0.890$ & $0.105)$ \\
\hline S11 & $(0.84$ & $0.14)$ & $(0.83$ & $0.17)$ & $(0.82$ & 0.18) & $(0.81$ & 0.19) & $(0.78$ & $0.18)$ & $(0.72$ & $0.28)$ & $(0.826$ & $0.163)$ \\
\hline S12 & $(0.91$ & ) & 9 & $0.11)$ & $(0.80$ & $0.20)$ & 9 & $0.21)$ & $(0.78$ & $0.22)$ & $(0.71$ & 0.29) & $(0$ & 0.129) \\
\hline S13 & $(0.89$ & $0.11)$ & $(0.87$ & $0.13)$ & $(0.78$ & $0.10)$ & $(0.80$ & $0.15)$ & $(0.81$ & 0.19) & $(0.69$ & $0.31)$ & $(0.853$ & $0.122)$ \\
\hline S14 & $(0.85$ & $0.15)$ & $(0.83$ & $0.16)$ & $(0.83$ & 0.17) & $(0.82$ & $0.18)$ & $(0.81$ & $0.19)$ & $(0.79$ & $0.21)$ & $(0.838$ & $0.162)$ \\
\hline S15 & $(0.94$ & $0.01)$ & $(0.84$ & $0.16)$ & $(0.82$ & $0.18)$ & $(0.81$ & 0.19) & $(0.79$ & $0.21)$ & $(0.74$ & $0.26)$ & 91 & $0.047)$ \\
\hline S16 & $(0.86$ & $0.10)$ & $(0.87$ & 0.13) & 0.83 & 0.17) & $(0.81$ & 0.19) & $(0.80$ & $0.20)$ & $(0.78$ & $0.22)$ & $(0.847$ & $0.131)$ \\
\hline S17 & $(0.79$ & $0.16)$ & $(0.80$ & $0.20)$ & $(0.79$ & $0.21)$ & $(0.78$ & $0.22)$ & $(0.72$ & $0.28)$ & $(0.71$ & 0.29) & $(0.786$ & $0.189)$ \\
\hline S18 & $(0.85$ & $0.15)$ & $(0.83$ & 0.17 ) & $(0.81$ & 0.19) & $(0.79$ & $0.21)$ & $(0.73$ & $0.27)$ & $(0.65$ & $0.35)$ & $(0.824$ & $0.176)$ \\
\hline S19 & $(0.91$ & (0.09) & $(0.90$ & $0.10)$ & $(0.89$ & $0.11)$ & $(0.87$ & 0.13) & $(0.80$ & $0.20)$ & $(0.76$ & 0.24) & $(0.894$ & $0.106)$ \\
\hline
\end{tabular}


In this regard, the ranks of strategies are determined through comparison of their score degree $s\left(\tilde{a}_{i}\right)$ and accuracy degree $h\left(\tilde{a}_{i}\right)$ considering total supply chain perspective. The same process should be applied in order to determine the ranks of strategies in three other perspectives. These ranks are observable in Table 7.

Table 7. The ranks of strategies in 4 different perspectives

\begin{tabular}{|c|c|c|c|c|c|}
\hline & \multirow{2}{*}{ Strategy } & \multicolumn{4}{|c|}{ Ranks in perspectives of: } \\
\hline & & Total supply chain & Supply & Production & Distribution \\
\hline $\mathrm{S} 1$ & $\begin{array}{l}\text { Increase transparency and } \\
\text { coordination }\end{array}$ & 1 & 10 & 1 & 4 \\
\hline S2 & $\begin{array}{l}\text { The use of insurance for premium } \\
\text { compensation }\end{array}$ & 5 & 5 & 8 & 1 \\
\hline $\mathrm{S} 3$ & Flexible transportation & 2 & 1 & 12 & 5 \\
\hline $\mathrm{S} 4$ & Safety stock of critical components & 6 & 3 & 11 & 3 \\
\hline S5 & Supply chain security management & 8 & 4 & 3 & 11 \\
\hline S6 & Influencing the customer's choice & 12 & 12 & 10 & 2 \\
\hline S7 & Keep track of weather forecasts & 14 & 17 & 2 & 7 \\
\hline S8 & $\begin{array}{l}\text { Redesign of products with risk- } \\
\text { sharing approach }\end{array}$ & 11 & 2 & 17 & 12 \\
\hline S9 & $\begin{array}{l}\text { Increasing the transparency of } \\
\text { transportation }\end{array}$ & 15 & 14 & 4 & 9 \\
\hline S10 & Multiple sourcing & 5 & 7 & 14 & 6 \\
\hline S11 & $\begin{array}{l}\text { Locating via consideration of safety } \\
\text { elements }\end{array}$ & 16 & 9 & 6 & 15 \\
\hline S12 & $\begin{array}{l}\text { Supplier selection and capable } \\
\text { transport equipment }\end{array}$ & 7 & 6 & 11 & 18 \\
\hline S13 & Multiple facilities & 9 & 8 & 15 & 8 \\
\hline S14 & Monitoring events and incidents & 13 & 18 & 5 & 13 \\
\hline $\mathrm{S} 15$ & $\begin{array}{l}\text { Create a secure communications } \\
\text { network }\end{array}$ & 3 & 13 & 7 & 17 \\
\hline S16 & Excess inventory & 10 & 11 & 16 & 10 \\
\hline S17 & Action against terrorist threats & 18 & 19 & 9 & 16 \\
\hline S18 & Standardization of various processes & 17 & 15 & 18 & 14 \\
\hline S19 & $\begin{array}{l}\text { Efficient human resource } \\
\text { management }\end{array}$ & 4 & 16 & 13 & 19 \\
\hline
\end{tabular}

\section{Discussions}

However, it can be understood from Table 7 that the strategy "increase transparency and coordination" from the perspective of total supply chain and also from the perspective of companies in production domain has got the best rank while from the perspective of companies in the domain of supply, the strategy of "flexible transportation" receives this position. At last and with similar analysis it can be determined from the perspective 
of companies in distribution domain of the supply chain that the strategy of "the use of insurance for premium compensation" has the best rank.

The results can be interpreted in this way that transparent organizations clearly define corporate structure and shape coordinated departments with clear responsibilities. They also pay attention to making clear relationships with other organizations. This transparency and coordination can help reduce confusion and accelerate action if and when a disruptive event occurs (Culp 2013). Another point is that transparency is considered as an essential attribute of any robust brand in this age that customers are informed and empowered (Grenville 2014). Besides, managers in production domain of the supply chain are usually much more focused on final product brand management. That is why it seems logical that the strategy of "increase transparency and coordination" has been determined as the most important strategy among the 19 ones in these 2 mentioned perspectives.

On the other hand, transportation system has an irrefutable role in shipping materials and constitutes one of the most important responsibilities of companies in the supply domain. So surely flexibility of transport system makes supply domain of the supply chain to become capable of doing this responsibility in different circumstances (Jabbarzadeh et al. 2016). However, as is clear from the results of Table 6, managers in the distribution domain have paid more attention to the matter of insurance and compensation of losses.

It is also notable that the highest standard deviation among the ranks of these strategies is related to the strategy 7 - "keep track of weather forecasts". Managers of companies in the production domain have announced that this strategy is among the most important ones while managers from the supply domain do not believe this matter. Meanwhile, the least standard deviation is observable among the ranks of strategy 18 - "Standardization of various processes". It seems that managers in different domains of supply, production and distribution do not believe the priority of this strategy. Such results should be shared with managers for making more interpretations.

\section{Conclusions and implications of the study}

The complexity of today's competitive market has made supply networks more vulnerable in the face of disruption and has caused serious management challenges. Therefore, forecasts and deployment of strategies for mitigation of such disruptions especially in supply chains such as petroleum supply chain that has undeniable effect on every aspect of life, have received increasing importance. Since the implementation of disruption management strategies has been accompanied by the imposition of significant costs, the use of all appropriate strategies for each chain is impossible. This shows the importance and sensitivity of choosing the best strategy.

Via the approach that is presented in this paper, it is possible to identify the most important indicators related to prioritization of strategies in the supply chain in addition to determination of the best strategy in the perspective of total supply chain and also companies in supply, production and distribution domains. 
The results show that the most important strategy from each perspective of supply, production and distribution is not necessarily as same as the most important strategy in total supply chain. This matter should be considered in making strategic decisions for designing the supply chain and definition of relations among companies.

Concluding previous studies shows that it is the first time a decision making process is generated using intuitionistic fuzzy Choquet integral, fuzzy AHP and BSC. The suggested method helps managers making more realistic decisions especially in strategic levels which is considered in this study, but surely can be applicable in tactical and even operational decisions where criteria and their weights follow fuzzy manner.

In this paper, disruption management strategies in petroleum supply chain are taken into account and their priorities are determined. Such an approach can be taken to deal with disruptions in other kinds of supply chains. Besides, sustainable supply chains and their special disruptions can be under consideration. Development of quantitative model for disruption mitigation in a supply chain is worthy. This approach can be taken for each kind of disruption or a combination of them. For example, investigation about this matter that how performance should be obtained by coordinating different members of supply chain with each other under production disruption can be an interesting research subject.

\section{References}

Adhitya, A.; Srinivasan, R.; Karimi, I. A. 2007. A model-based rescheduling framework for managing abnormal supply chain events, Computers \& Chemical Engineering 31(5): 496-518. https://doi.org/10.1016/j.compchemeng.2006.07.002

Alcantara, P.; Riglietti, G. 2016. Supply chain resilience report 2016, Business Continuity Institute: 44 [online], [cited 9 February 2017]. Available from Internet: https:/www.riskmethods.net/ resources/research/bci-supply-chain-resilience-2015.pdf

Alexander, D. E. 1993. Natural disasters. Springer Science \& Business Media.

Applequist, G. E.; Pekny, J. F.; Reklaitis, G. V. 2000. Risk and uncertainty in managing chemical manufacturing supply chains, Computers \& Chemical Engineering 24(9): 2211-2222.

https://doi.org/10.1016/S0098-1354(00)00585-8

Azadi, M.; Jafarian, M.; Saen, R. F.; Mkirhedayatian, S. M. 2015. A new fuzzy DEA model for evaluation of efficiency and effectiveness of suppliers in sustainable supply chain management context, Computers \& Operations Research 54: 274-285.

https://doi.org/10.1016/j.cor.2014.03.002

Azaron, A.; Brown, K. N.; Tarim, S. A.; Modarres, M. 2008. A multi-objective stochastic programming approach for supply chain design considering risk, International Journal of Production Economics 116(1): 129-138. https://doi.org/10.1016/j.ijpe.2008.08.002

Bai, Y.; Zhou, P.; Zhou, D. Q.; Meng, F. Y.; Ju, K. Y. 2016. Desirable policies of a strategic petroleum reserve in coping with disruption risk: a Markov decision process approach, Computers \& Operations Research 66: 58-66. https://doi.org/10.1016/j.cor.2015.07.017

Bakshi, N.; Kleindorfer, P. 2009. Co-opetition and investment for supply-chain resilience, Production and Operations Management 18(6): 583-603.

Barros, M. M.; Szklo, A. 2015. Petroleum refining flexibility and cost to address the risk of ethanol supply disruptions: the case of Brazil, Renewable Energy 77: 20-31.

https://doi.org/10.1016/j.renene.2014.11.081 
Behdani, B. 2013. Handling disruptions in supply chains: an integrated framework and an agentbased model: PhD thesis. Next Generation Infrastructures Foundation.

Birkie, S. E.; Trucco, P.; Kaulio, M. 2014. Disentangling core functions of operational resilience: a critical review of extant literature, International Journal of Supply Chain and Operations Resilience 1(1): 76-103. https://doi.org/10.1504/IJSCOR.2014.065461

Bueno-Solano, A.; Cedillo-Campos, M. G. 2014. Dynamic impact on global supply chains performance of disruptions propagation produced by terrorist acts, Transportation Research Part E: Logistics and Transportation Review 61: 1-12. https://doi.org/10.1016/j.tre.2013.09.005

Cavinato, J. L. 2004. Supply chain logistics risks: from the back room to the board room, International Journal of Physical Distribution \& Logistics Management 34(5): 383-387.

https://doi.org/10.1108/09600030410545427

Chen, K.; Xiao, T. 2015. Outsourcing strategy and production disruption of supply chain with demand and capacity allocation uncertainties, International Journal of Production Economics 170: 243-257. https://doi.org/10.1016/j.ijpe.2015.09.028

Chopra, S.; Sodhi, M. S. 2004. Managing risk to avoid supply-chain breakdown, MIT Sloan Management Review 46(1): 53.

Costantino, F.; Gravio, G. D.; Shaban, A.; Tronci, M. 2014. Replenishment policy based on information sharing to mitigate the severity of supply chain disruption, International Journal of Logistics Systems and Management 18(1): 3-23. https://doi.org/10.1504/IJLSM.2014.062119 Coutu, D. L. 2002. How resilience works, Harvard business review 80(5): 46-56.

Culp, S. 2013. Supply Chain Disruption - a major threat to business, Forbes [online], [cited 11 February 2017]. Available from Internet: http://www.forbes.com/sites/steveculp/2013/02/15/ supply-chaindisruption-a-major-threat-to-business.

Dobie, G. 2015. Global claims review 2015 [online], [cited 11 February 2017]. Available from Internet: www.agcs.allianz.com

EIA. 2016. Unplanned global oil supply disruptions reach highest level since at least 2011, Today in Energy [online], [cited 9 February 2017]. Available from Internet: http://www.eia.gov/ todayinenergy/detail.php?id=26592

Finch, P. 2004. Supply chain risk management, Supply Chain Management: An International Journal 9(2): 183-196. https://doi.org/10.1108/13598540410527079

Gao, L. 2015. Collaborative forecasting, inventory hedging and contract coordination in dynamic supply risk management, European Journal of Operational Research 245(1): 133-145.

https://doi.org/10.1016/j.ejor.2015.02.048

Giri, B. C.; Sarker, B. R. 2017. Improving performance by coordinating a supply chain with third party logistics outsourcing under production disruption, Computers \& Industrial Engineering 103: 168-177. https://doi.org/10.1016/j.cie.2016.11.022

Grenville, A. 2014. 5 ways of increasing brand transparency to strengthen customer loyalty [online], [cited 9 February 2017]. Available from Internet: https://www.visioncritical.com/betransparent/

Gülpınar, N.; Canakoglu, E.; Pachamanova, D. 2014. Robust investment decisions under supply disruption in petroleum markets, Computers \& Operations Research 44: 75-91.

https://doi.org/10.1016/j.cor.2013.08.006

Güngör, Z.; Serhadlığlu, G.; Kesen, S. E. 2009. A fuzzy AHP approach to personnel selection problem, Applied Soft Computing 9(2): 641-646. https://doi.org/10.1016/j.asoc.2008.09.003

Hallikas, J.; Karvoneh, I.; Pulkkineh, U.; Virolainen, V.; Touminen, M. 2004. Risk management processes in supplier networks, International Journal of Production Economics 90(1): 47-58. https://doi.org/10.1016/j.ijpe.2004.02.007 
Hao, Z.; Xu, Z.; Zhao, H.; Zhang, R. 2017. Novel intuitionistic fuzzy decision making models in the framework of decision field theory, Information Fusion 33: 57-70.

https://doi.org/10.1016/j.inffus.2016.05.001

Hosseini, S.; Al Khaled, A. 2016. A hybrid ensemble and AHP approach for resilient supplier selection, Journal of Intelligent Manufacturing, 1-22 (in press).

https://doi.org/10.1007/s10845-016-1241-y

Ivanov, D.; Dolgui, A.; Sokolov, B.; Ivanova, M. 2016a. Disruptions in supply chains and recovery policies: state-of-the art review, IFAC-PapersOnLine 49(12): 1436-1441.

https://doi.org/10.1016/j.ifacol.2016.07.773

Ivanov, D.; Pavlov, A.; Sokolov, B. 2014. Optimal distribution (re) planning in a centralized multi-stage supply network under conditions of the ripple effect and structure dynamics, European Journal of Operational Research 237(2): 758-770. https://doi.org/10.1016/j.ejor.2014.02.023

Ivanov, D.; Tsipoulanidis, A.; Schönberger, J. 2016b. Global suppy chain and operations management. Springer.

Ivanov, D.; Tsipoulanidis, A.; Schönberger, J. 2017. Inventory management, in Global supply chain and operations management. Springer, 345-388.

https://doi.org/10.1007/978-3-319-24217-0_13

Jabbarzadeh, A.; Fahimnia, B.; Sheu, J.; Moghadam, H. S. 2016. Designing a supply chain resilient to major disruptions and supply/demand interruptions, Transportation Research Part B: Methodological 94: 121-149. https://doi.org/10.1016/j.trb.2016.09.004

Johnson, M. E. 2001. Learning from toys: lessons in managing supply chain risk from the toy industry, California Management Review 43(3): 106-124. https://doi.org/10.2307/41166091

Kamalahmadi, M.; Parast, M. M. 2016. An assessment of supply chain disruption mitigation strategies, International Journal of Production Economics 184: 210-230.

https://doi.org/10.1016/j.ijpe.2016.12.011

Katata, K. 2011. Disruption risks and robust investment strategies in petroleum markets: $\mathrm{PhD}$ thesis. University of Warwick, UK.

Kazemi, Y.; Szmerekovsky, J. 2015. Modeling downstream petroleum supply chain: the importance of multi-mode transportation to strategic planning, Transportation Research Part E: Logistics and Transportation Review 83: 111-125. https://doi.org/10.1016/j.tre.2015.09.004

Kean, V. A. 2009. The petroleum disruption response system [online], [cited 9 February2017]. Available from Internet: http://hdl.handle.net/10919/41502

Kiser, J.; Cantrell, G. 2006. 6 steps to managing risk, Supply Chain Management Review 10(3): $12-17$.

Kleindorfer, P. R.; Saad, G. H. 2005. Managing disruption risks in supply chains, Production and Operations Management 14(1): 53-68.

Lee, H. L.; Wolfe, M. 2003. Supply chain security without tears, Supply Chain Management Review 7(3): 12-20.

Letza, S. R. 1996. The design and implementation of the balanced business scorecard: an analysis of three companies in practice, Business Process Re-engineering \& Management Journal 2(3): 54-76. https://doi.org/10.1108/14637159610151217

Li, X.; Wang, L. 2015. Strategy decision of business interruption insurance and emergency supply strategy based on supply disruptions, Journal of Industrial Engineering and Management 8(1): 110-121. https://doi.org/10.3926/jiem.1346

Lim, M..; Bassamboo, A.; Chopra, S.; Daskin, M. S. 2013. Facility location decisions with random disruptions and imperfect estimation, Manufacturing \& Service Operations Management 15(2): 239-249. https://doi.org/10.1287/msom.1120.0413 
Manuj, I.; Mentzer, J. T. 2008. Global supply chain risk management strategies, International Journal of Physical Distribution \& Logistics Management 38(3): 192-223.

https://doi.org/10.1108/09600030810866986

Martha, J.; Vratimos, E. 2002. Creating a just-in-case supply chain for the inevitable next disaster, Mercer Management Journal 14(1): 70-77.

Martin, T. D.; Bell, J. T. 2016. New horizons in standardized work: techniques for manufacturing and business process improvement. CRC Press.

Mitroff, I. I.; Alpaslan, M. C. 2003. Preparing for evil. Harvard Business School Pub.

Murphy, S. 2006. BGP security vulnerabilities analysis.

Norton, D.; Kaplan, R. 1993. Putting the balanced scorecard to work, Harvard Business Review 71(5): 134-140.

Oehmen, J.; Ziegenbein, A.; Alard, R.; Schonsleben, P. 2009. System-oriented supply chain risk management, Production Planning and Control 20(4): 343-361.

https://doi.org/10.1080/09537280902843789

Officials, S. E. 2006. Petroleum shortage supply management: options for states [online], [cited 9 February 2017]. Available from Internet: www.naseo.org

Park, K.; Min, H.; Min, S. 2016. Inter-relationship among risk taking propensity, supply chain security practices, and supply chain disruption occurrence, Journal of Purchasing and Supply Management 22(2): 120-130. https://doi.org/10.1016/j.pursup.2015.12.001

Paul, S. K.; Sarker, R.; Essam, D. 2017. A quantitative model for disruption mitigation in a supply chain, European Journal of Operational Research 257(3): 881-895.

https://doi.org/10.1016/j.ejor.2016.08.035

Paul, S. K.; Sarker, R.; Essam, D. 2014. Managing real-time demand fluctuation under a supplier-retailer coordinated system, International Journal of Production Economics 158: 231-243. https://doi.org/10.1016/j.ijpe.2014.08.007

Peck, H. 2005. Drivers of supply chain vulnerability: an integrated framework, International Journal of Physical Distribution \& Logistics Management 35(4): 210-232.

https://doi.org/10.1108/09600030510599904

Pender, B.; Currie, G.; Delbosc, A.; Shiwakoti, N. 2013. Disruption recovery in passenger railways: international survey, Transportation Research Record: Journal of the Transportation 2353: 22-32. https://doi.org/10.3141/2353-03

Rafiei, M.; Mohammadi, M.; Torabi, S. 2013. Reliable multi period multi product supply chain design with facility disruption, Decision Science Letter 2(2): 81-94.

https://doi.org/10.5267/j.ds1.2013.02.002

Rangel, D. A.; de Oliveira, T. K.; Leite, M. S. A. 2015. Supply chain risk classification: discussion and proposal, International Journal of Production Research 53(22): 6868-6887.

https://doi.org/10.1080/00207543.2014.910620

Ratzmann, M.; Gudergan, S. P.; Bouncken, R. 2016. Capturing heterogeneity and PLS-SEM prediction ability: alliance governance and innovation, Journal of Business Research 69(10): 4593-4603. https://doi.org/10.1016/j.jbusres.2016.03.051

Revilla, E.; Sáenz, M. J. 2014. Supply chain disruption management: global convergence vs national specificity, Journal of Business Research 67(6): 1123-1135.

https://doi.org/10.1016/j.jbusres.2013.05.021

Rice, J. B.; Caniato, F. 2003. Building a secure and resilent supply network, Supply Chain Management Review 7(5): 22-30.

Robles, A.; Severson, R. 2016. Improving supply chain resilience for a fashion retailer: a qualitative and quantitative study: Master's Thesis. Massachusetts Institute of Technology. 
Schmidt, W.; Raman, A. 2012. When supply-chain disruptions matter. Harvard Business School Boston, MA.

Schmitt, T. G.; Kumar, S.; Stecke, K. E.; Glover, F. W.; Ehlen, M. A. 2017. Mitigating disruptions in a multi-echelon supply chain using adaptive ordering, Omega 68: 185-198.

https://doi.org/10.1016/j.omega.2016.07.004

Sharma, K. S.; Bhagwat, R. 2007. An integrated BSC-AHP approach for supply chain management evaluation, Measuring Business Excellence 11(3): 57-68.

https://doi.org/10.1108/13683040710820755

Sheffi, Y. 2001. Supply chain management under the threat of international terrorism, The International Journal of Logistics Management 12(2): 1-11. https://doi.org/10.1108/09574090110806262

Sheffi, Y.; Rice, J. 2005. Building the Resilient Enterprise, MIT Sloan Management Review 47(1): 41-48.

Simchi-Levi, D.; Schmidt, W.; Wei, Y.; Shang, P. U.; Combs, K.; Ge, Y.; Gusikhin, O.; Sanders, M.; Zhang, D. 2015. Identifying risks and mitigating disruptions in the automotive supply chain, Interfaces 45(5): 375-390. https://doi.org/10.1287/inte.2015.0804

Snyder, L. V.; Atan, Z.; Peng, P.; Rong, Y.; Schmitt, A. J.; Sinsoysal, B. 2012. Or/ms models for supply chain disruptions: a review, IIE Transactions 48(2): 89-109.

https://doi.org/10.1080/0740817X.2015.1067735

Stecke, K. E.; Kumar, S. 2009. Sources of supply chain disruptions, factors that breed vulnerability and mitigating strategies, Journal of Marketing Channels 16(3): 193-226.

https://doi.org/10.1080/10466690902932551

Tan, C.; Chen, X. 2010. Intuitionistic fuzzy Choquet integral operator for multi-criteria decision making, Expert Systems with Applications 37(1): 149-157.

https://doi.org/10.1016/j.eswa.2009.05.005

Tang, C. S. 2006. Robust strategies for mitigating supply chain disruptions, International Journal of Logistics: Research and Applications 9(1): 33-45. https://doi.org/10.1080/13675560500405584

Tang, O.; Nurmaya Musa, S. 2011. Identifying risk issues and research advancements in supply chain risk management, International Journal of Production Economics 133: 25-34.

https://doi.org/10.1016/j.ijpe.2010.06.013

Tomlin, B. 2006. On the value of mitigation and contingency strategies for managing supply chain disruption risks, Management Science 52(5): 639-657. https://doi.org/10.1287/mnsc.1060.0515

Vahdani, B.; Zandieh, M.; Roshanaei, V. 2011. A hybrid multi-stage predictive model for supply chain network collapse recovery analysis: a practical framework for effective supply chain network continuity management, International Journal of Production Research 49(7): 2035-2060. https://doi.org/10.1080/00207540903289748

Vakharia, A. J.; Yenipazarli, A. 2009. Managing supply chain disruptions, Foundations and Trends in Technology, Information and Operations Management 2(4): 243-325.

https://doi.org/10.1561/0200000012

Wang, Y. M.; Chin, K. S. 2011. Fuzzy analytic hierarchy process: a logarithmic fuzzy preference programming methodology, International Journal of Approximate Reasoning 52(4): 541-553. https://doi.org/10.1016/j.ijar.2010.12.004

WKP. 2015. Petroleum industry, 1-4 [online], [cited 9 February 2017]. Available from Internet: http://www.slideshare.net/MickeyOtterlei/petroleum-industry-final

$\mathrm{Xu}, \mathrm{Z}$. 2010. Choquet integrals of weighted intuitionistic fuzzy information, Information Sciences 180(5): 726-736. https://doi.org/10.1016/j.ins.2009.11.011

Yeletaysi, S. 2009. A risk analysis on the continuity of the petroleum supply chain using GIS and systems simulation. The George Washington University. 
Yeniyurt, S. 2003. A literature review and integrative performance measurement framework for multinational companies, Marketing Intelligence \& Planning 21(3): 134-142.

https://doi.org/10.1108/02634500310474957

Zsidisin, G. A.; Ellram, L. M. 2003. An agency theory investigation of supply risk management, Journal of Supply Chain Management 39(3): 15-27.

Fatemeh GHASEMZADEH is currently $\mathrm{PhD}$ candidate of operation and production management at the School of Management and Accounting of Allameh Tabataba'I University, Tehran, Iran. She is working on her Thesis on the Supply Chain Disruption Management. She has published papers with the focus on Supply Chain Management and Production Planning. Her research interests include supply chain management, inventory management, multi criteria decision making and production planning and management.

Mahsa PISHDAR has finished her PhD of operation and production management at the School of Management and Accounting of Allameh Tabataba'I University, Tehran, Iran. She is visiting lecturer at different colleges. She has published papers with the focus on multi criteria decision making and Supply Chain Management. Her research interests include multi criteria decision making, DEA, supply chain management and inventory management.

Jurgita ANTUCHEVIČIENE is Professor at the Department of Construction Management and Real Estate of Vilnius Gediminas Technical University, Vilnius, Lithuania. She received a $\mathrm{PhD}$ in Civil Engineering in 2005. She is author and co-author of about 80 scientific papers. Research interests include multiple criteria analysis, decision-making theories and decision support systems, sustainable development, construction management and investment. 